Current Research in Psychology 1 (1): 1-15, 2010

ISSN 1949-0178

(C) 2010 Science Publications

\title{
Towards the Decline and fall of Radical and Educational Constructivism (Mark I)
}

\author{
${ }^{1}$ James Carifio and ${ }^{2}$ Rocco J. Perla \\ ${ }^{1}$ Graduate School of Education, University of Massachusetts Lowell, Lowell, MA., USA \\ ${ }^{2}$ HealthAlliance Hospitals, Inc., Leominster, MA., USA
}

\begin{abstract}
Problem statement: In 1974, McKeachie published a brief article in The Educational Researcher called, "The Decline and Fall of the Laws of Learning". Approach: This article was primarily about the decline and fall of the behaviorist laws of learning and radical behaviorism, both of which were never quite the same in psychology or education after this article as before it was published. The purpose of the present article is to start of the process of developing and refining a series of core and critical analyses of radical constructivism, modified (radical) constructivism and "educational constructivism' that will initiate the process of the decline and fall of these views from educational circles and certain psychological and sociological circles and have these flavors of constructivism replaced by modern, sound, empirically documented and supported views and theories (yes, theories) of learning and cognition. Results: Our purpose is to begin the process of doing a critique similar to McKeachie's on "educational constructivism", as it is as unscientific and misguided as behaviorism was in the sixties and not much different from behaviorism in the sixties, as it is in numerous ways the opposite end of the same misguided and non-scientific continuum and more of a philosophy of learning than a scientific theory. The criticisms of constructivism to date have primarily been philosophical as opposed to psychological, learning theory centered and scientific theory centered, which is the primary focus in this article. As many leading scholars have noted, (educational) constructivism is the dominant paradigm and "theory" in science education and social science education today. Science education in particular simply cannot have a dominant paradigm that is unscientific, non-theoretical in the modern sense of scientific theory and essentially "Creationist Science" in character. Conclusion: This current state of affairs is simply too radical of a core contradiction and cannot be supported or maintained any longer as an egocentric fad that may simply pass on and fade away. The "McKeachie Cycle" for these flavors of constructivism needs to both begin and quickly end.
\end{abstract}

Key words: Radical constructivism, educational constructivism, learning theory, learning philosophy, science education, social science education, cognitive learning theory, critical analysis

\section{INTRODUCTION}

In 1974, (McKeachie, 1974; Carifio, 2005), who was later president of the American Psychological Association, wrote a fairly stunning (for the times) and now both famous and classic article (at least in some circles) published in The Educational Researcher called, "The Decline and Fall of the Laws of Learning". Basically, what this article was about was the decline and fall of the behaviorist laws of learning and radical behaviorism, both of which were never quite the same in psychology or education after this article as before, as they were both finally reduced from wildly vague, shallow, over generalized and sloganeering "theory" to a (very) limited set of empirical and functional observational effects in search of an adequate theory and cogent explanation. Great empirical and experimental gaps were found between the rhetoric and the reality of behaviorism when it came to a wide variety of different kinds of human learning.

What was most stunning about this article, however, is that McKeachie (along with most other American educators and psychologists) had been one of the most respected and leading proponents of the radical behaviorism of B.F. Skinner a decade before publishing this article. Yet, McKeachie laid out very meticulously and succinctly in his very brief article, why radical behaviorism was both misguided and essentially incorrect, did not hold together theoretically, was not really a psychological theory, or theory of learning, or

Corresponding Author: James Carifio, Graduate School of Education, University of Massachusetts Lowell, Lowell, MA., USA 
theory at all, except in a narrow and limited empirical and logical positivist sense and how each of the major claims, which were 10 in number, were clearly and definitely contradicted by major empirical data from large volumes of studies, particularly when it came to classroom, academic, intellectual and higher-order learning, problem-solving, inventiveness and originality.

McKeachie also pointed out the massive amounts of empirical data and simple observable facts Skinner ignored in his radical Grand (but not unified) Theory of Everything (as did Chomksy in "the Great Debate"), because for Skinner there basically was only one kind and way of learning and thus learning theory and he was the pharaoh bringing this "newly discovered monism" to psychology and education. This particular characteristic, (Pinker, 2002) has pointed out, tends to be true of most radical theories in all domains (e.g., Mao's little red book and re-education theory) and not just psychology or learning theory. In other articles, McKeachie also pointed out the self-contradictory aspects of behaviorism and the "behaviorism program and paradigm" as (Popper, 1969) would say (McKeachie, 1976).

What McKeachie also did in his brief article in 1974 was to show that behaviorism and it rise and decades of wide-spread fervent advocacies and advocates were in great part ideological and philosophical as opposed to science-based and scientific in nature and character and that these problems were endemic to radicalisms of all kinds and what passed for theory in the social sciences and education at that time. These were very clarion and prescient claims and views, as one will recall that (Suppes, 1979) classic and definitive work on the Structure of Scientific Theories was published soon thereafter and (Lakatos, 1970) now widely accepted initial work on the general nature of theory was published a few years earlier. Kuhn (1996) classic work on the post-positivist view of science and scientific theories had also just been published, as well as Neisser (1967) revolutionary book on cognitive psychology and Norman (1976) classic book on informational processing theories of learning. It was a very rapid and fast moving period of change in psychology, education and science and the cusp of a paradigm shift and the beginnings of the cognitive revolution in psychology and the emergence of the cognitive sciences (Hooper and Teresi, 1991; Green, 1998). This paradigm shift also lead to the period of the "great void" in the eighties in education (and rushes to fill it) and then the period of "rapid (and out of control) speciation" of theories and models in the nineties (Carifio, 2005). And, quite importantly, even neobehaviorism and its variants were rapidly crumbling from cogent criticism during this period (Carifio, 1979; 1993; Penrose, 1991).

What McKeachie also did in this article (and subsequently elsewhere) was most probably an absolute first in the social sciences (never mind education), which was that he admitted publicly and in writing that he had been incorrect, had tenaciously held a basically incorrect view and theory and that simple logic, arguments and observational data from study after study had shown this (alleged) theory to be incorrect or extremely tenuous, vague and imprecise at best and that the evidence available actually better supported alternatives views! Note, McKeachie did not recant his position, which is what one does with an ideology. Rather, McKeachie did what scientists do quite often and often in their own careers as scientists nowadays, he rejected a paradigm and its associated theory and tentatively adopted an alternative competing paradigm and associated theory because that is what the cumulative weight of evidence, logical analysis and critical argument indicated was the appropriate decision to make and professional thing to do. In other words, he accepted the results of falsification tests even though the results and findings of such tests were not in favor of his existing theoretical views.

In short, McKeachie abided by the agreed upon rules and process of scientific decision-making and science and acted like a model scientist and "did some good science," which is not something that happens often in the social science or education by proponents, leading advocates, or founders of various positions, views and theories. There are several important reasons why "good (modern) science" and "good (modern) scientific decision-making" does not occur in psychology, but particularly so in education, which will be addressed at some point in this article (and series of articles), but the point here is that McKeachie's work, approach and stance is not only an exemplar for us all, but an effort that sorely needs to be repeated and replicated with the philosophy (as it is no scientific theory) of learning in education and particularly science education, that is know as radical constructivism and even modified radical (or more appropriately educational) constructivism, as what is meant by constructivism in education and science education circles is not the same as what is meant by constructivism in modern (mainstream) psychological and learning theory circles, regardless of the spurious and unverified claims to the contrary and the lack of close, knowledgeable and detailed analysis of these key and very differing, incommensurate and fundamental core views. This particular and fundamentally important point will be discussed in more detail below. 
The point here is that radical and educational constructivism and its variants are not much different from radical behaviorism and its variants (including neobehaviorism and instructional theory) and the (Frankfurt, 2005) rhetoric and various empty platitudes, slogans and statements associated with radical and educational constructivism need to go to the same place radical behaviorism and its variants went in education and particularly in science education, as radical and educational constructivism is basically anti-scientific in character relative to what is normatively meant by science today among mainstream philosophers of science and practicing scientists. In a word, a "McKeachie Critique" is really and sorely need just now of radical and educational constructivism.

Purpose: The purpose of this article is to start of the process of developing and refining a series of core and critical analyses of radical constructivism, modified (radical) constructivism and "educational constructivism' that will initiate the process of the decline and fall of these views from educational circles and science education circles in particular and have them replaced by modern, sound, empirically documented and supported views and theories (yes, theories) of learning. Our purpose here is to begin the process of doing a "McKeachie Critique" on "educational constructivism", as it is as unscientific and misguided as behaviorism was in the sixties in education and not much different from behaviorism in the sixties, as it is in numerous ways the opposite end of the same misguided and non-scientific continuum. It is not without great significance that Skinner and (very, very old fashion) behaviorism is the bete noir and continually comparative Aunt Sally straw person of von (Von Glaserfeld, 1995; 2005) and his many proponents in their reactionary (and uninformed) radicalism against a reactionary (and uniformed) radicalism. To many, these two views are not substantively different theories of learning (Pinker, 1997; 1999; 2002), but rather polar ideologies anachronistically clashing against each other long after the associated disciplines have move on elsewhere.

Unfortunately, however, the first and key irony that must be understood and appreciated here is the current core and pervasive "learning theory" in science education (and social science education) is unscientific and not a scientific theory at all by modern definitions and criteria. This state of affairs simply cannot be or be accepted and must be strongly and continuously challenged (even though it has been by a stellar "rear guard' for over fifteen years similar to the "distaff voices" in the very early days of the cognitive revolution) until very fundamental and very needed changes are achieved. There are, however, so many points that are in error, misguided and contradicted by fundamental observations and empirical data that one can only address a few at one time in a article, which is the strategy that will be used here. This article, therefore, is the first of several articles we will write on this topic and problem recognizing that some scholars in the science education community recognize similar concerns and issues relative to constructivism, but that these scholars are clearly in the minority (Fensham, 2004; Matthews, 2000; Osborne, 1996).

If proponents of educational constructivism take their views and assumptions seriously and scientifically, then they will welcome informed criticism. Whether educational constructivists in the area of science education are capable or interested in such discourse, however, is, without doubt, a key issue, point and concern. As (Matthews, 1997) has noted:

Unfortunately matters of deep philosophical importance over which there have been centuries of debate too frequently appear almost as throw away lines in science education writing. When they are elaborated, the elaboration is often slight, being little more than the citing of names...overall the theoretical, pedagogical and curriculum proposals of educational constructivism are like an inverted pyramid: they rest on a tiny base. It is in everyone's interest that this base be made more substantial and be well scrutinized (p. 8).

One of us (Carifio, 2005) recently echoed the same sentiment in characterizing the superficial and often shallow nature in which theoretical referents are "fished from" the psychological literature (or stream) by educational researchers in general and science and social studies educators in particular. This article, therefore, looks to begin the development of a "more substantial and well scrutinized" critique of educational constructivism from the perspective of main stream and current cognitive psychology (see the section on "that turn-of-the-(last) century show" below), which is a much need perspective in this important issue and debate.

Prior criticism of (educational) constructivism: Most of the criticism of constructivism in education has been by philosophers (Cobb, 1994: Matthews, 1994; 1997; Nola, 1997; Sokal and Bricmont, 1998; Suchting, 1992) and educators with fairly good philosophical and learning theory backgrounds (Mayer, 2004; Osborne, 1996). To many today and in the past in both philosophy and psychology, "constructivism" (in the radically subjective and phenomenological form) was pretty much "decided and put to bed" when Johnson 
dropped the boulder on Bishop Berkley's foot in 1763 and told him that the pain he was "experiencing" was only an imaginary (mental) construction actively initiated by Berkley (and currently deceiving him), which had nothing to do with Johnson or the subjective worlds either of them inhabited, which would just immediately disappear if the Bishop would just deconstructed and reconstructed his subjective experience and did so positively (according to various current new age therapists). Johnson said this to Berkley, it is reported, as he was walking away, leaving Berkley to his radical skepticism and subjectivism along with Hume in the dank drizzle of a typical bleak Edinburgh evening, which for many takes good doses of "grandma's tea" to endure, which raises several other questions about this famous discussion. Academic discourse, unfortunately, has changed in many quarters since 1763 , so we must adopt less vivid demonstrations of the points we wish to make now. The point here, however, is that key ideas about falsification, objective reality, thick and rich contextualization and the construction of knowledge and understanding have been around for a long time and are not all that new really, or many of the various arguments about them. As one constructivism critic quipped, quite correctly, current educational constructivism is actually not much more than many old wines in new bottles with Madison Avenue labels on them.

Matthews and others (Fensham, 2004; Matthews, 1993; 1997) have outlined the many difficulties, flaws, errors, illogicalities, contradictory experimental and observational evidence from a wide variety of scientific areas, as well as psychology, associated with radical and educational constructivism, in addition to (selectively) ignored evidence and philosophical and theoretical analysis and critical points. Both Matthews and Fensham should be read closely by all, as nothing really is a substitute for reading their fine works. However, to quickly and briefly summarize some of their major points to set the context of this article, it must be said that the general distaff or minority view (in certain circles) is that much if not most of the "doctrine known as constructivism ...is simply unintelligible. Second, to the extent that it is intelligible ...it is simply confused (p. 247) (Suchting, 1992)", circular and difficult in many instances to falsify. Suchting's points are not only very true, but the language and discourse of constructivism is extremely opaque, ambiguous, amorphous, shallow, vague, unscientific, unsubstantiated, contradicted and sloganeering (Fensham, 2004) and very similar to reading John Dewey and his advocates on what an "educative experience" is, which is one of Dewey's central constructs (and a circular one in our opinion).
These criticisms are cogent as the kind, quality, clarity and precision of language, adequate and clear constructs and operational definitions that are easily and clearly falsifiable and testable are the very hallmarks of science and good science as well as good theory of any and all kinds. That there is such a "language (and rhetoric and reality gap and) problem with constructivism (as there was with behaviorism) is the very key indicator that there are major and most likely uncorrectable problems with constructivism of these as opposed to other flavors. As the obfuscation index increases and the amount of sound experimental data decreases, one should know enough intellectual history to know that this condition signals very major problems.

Language, in the fullest sense and meaning of the word and term, was also one of the central, key and critical elements in the downfall of behaviorism. As (Chomsky, 1959) clearly demonstrated, the behaviorist concept and view of language was completely inadequate and behaviorism could not explain how a person produced or understood a novel sentence or sentence they never heard or encountered before. Neither can radical or educational constructivism and this basic problem is symptomatic of several of its core and root difficulties. There are many simple, but absolutely key every day phenomena (e.g., deception and humor) that neither behaviorism nor radical and educational constructivism can explain, which are key and core facts about human beings and the human condition that any minimally adequate psychology or learning theory must be able to account for in a reasonably cogent way. Behaviorists had no concept or understanding of language and linguistic universals (e.g., Esperanto) that were genetic in origin and character (and not the construction and invention of each new speaker) and thus common to all people in all times. Behaviorists had no concept or understanding of semantic memory or the generativity and generative processes (many of which are automatic) of semantic long term memory, which form part of the actual scientific underpinning of what is called psychological constructivism (Ashcraft, 1997; Bartlett, 1932; Chomsky, 1975; Collins and Loftus, 1975; Craik and Lockhart, 1972; Kintch, 1988; Neisser, 1967; Selfridge, 1959). Psychological constructivism is very different from radical or educational constructivism and constructivism in certain clinical and social areas of psychology and sociology. Behaviorists were naive about language and educational constructivists are also naive about language and its character and functioning in all of the same ways Piaget was and the majority of his proponents were until quite recently. Further, as has pointed out and elaborated in detail: 
The world is neither created by discourse (as in idealism and many versions of constructivism such as the Edinburgh School, Ernst von Glaserfeld and Rosalind Driver in unguarded moments), nor does it somehow created the discourse (in various reflection, or imprinting, theories from Locke to Lenin), nor does it anchor or provide foundations for discourse (as in empiricism and positivism). Theoretical discourse and the world are autonomous. In this sense, theory exists independently of individuals. Thus, scientific knowledge is, contrary to the claims of many constructivism, external to individuals (p. 8).

We cannot over-stress the importance of "the language issues" with radical and educational constructivism and how incorrect and outdated both are relative to these language issues, as the well as the core and central importance of language to science and to any theory of learning and human theory of learning in particular. Full explication of this point, however, will take an article all of its own, which bring us to our next central point and criticism.

Fensham (2004) points out that all of these critiques go largely unnoticed in education and particularly in science education, in part due to the fact that both professional preparation and daily professional practice do not put constructivist proponents in contact with these critiques and expertise, because the education of science educators and science education professors over the past fifteen years has been excessively narrow, shallow and lacking, particularly in the foundational areas and in the foundations of science. This same preparation criticism could also be made of certain areas of psychology and sociology. Fensham makes a very detailed case for his points as well as the consequences these points have had on the quality of science education research and writings. It is difficult to argue with Fensham given the extensity of his research on these points and a reading of science education research and other writings over the past fifteen years. This literature (as much educational and instructional literature) seems somewhat frozen in time somewhere around the late seventies (show) of Bruner, Gagne and Ausubel and disconnected from mainstream literature in the foundational areas subsequent to that point (somewhat like the Galapagos islands). In part, radical constructivism emerged to rapidly fill this seeming void and decoupling from the lifting rocket of cognitive psychology and the cognitive revolution and in part as a response to the various pressures of educational reform and the new "educational crisis" of the eighties and need to do something very different, or to appear to be doing so. However, beside all of the problems mentioned above these radical and educational constructivists, initiated what one of us (Carifio) calls the "turn of the (last) century show", as well as a shotgun eclecticism and indiscriminate and promiscuous borrowing of various outdated and incommensurate "bits and pieces" from the "research literature" to cobble together an "instructional theory" and a variety of instructional slogans and all of the cacophony and contradictions such eclectic borrowing brings theoretically.

The turn of the (last) century show: When one reads the radical constructivist and educational constructivist literature one encounters everywhere and in various forms Piaget and his genetic epistemology and "constructivism", as well as Vygotsky and essentially similar if not the same things. One would think that both psychology and learning theory was somewhat akin to a sacred and divinely revealed ancient text that in no way had been modified or significantly changed in the last century in any fundamentally crucial ways (which is definitely not the case or even close to the case). Not exactly what one would call a modern and post-positivist view of theory or theory change.

One would also think that very limited and developing children of less than age six, who have no choice but to employ a peculiar and limited type of "constructivism" were and are the exemplars for older and more mature students and adult learners. One would actually think from reading this literature that there were no qualitative developmental changes, or that Piaget's did not get vaguer and vaguer with "here a miracle occurs" theory and dismissal of language (and all that entails) as relatively inconsequential, as development occurred. One actually sees in this constructivist literature the somewhat startling phenomenon of adolescents, young adults and adult learners implicitly characterized and portrayed as oversized children, which has to be one of the intellectual inversions of all time, never mind the havoc this plays in various ways with learning theory let alone learning theories.

One completely loses the key idea and basic facts that one acquires increasing sophisticated and powerful capabilities as one develops, which makes one significantly different as a person and as a learner and that one may posit, represent, manipulate, predict, transform, test, falsify and tentatively know and know the degree to which one tentatively knows (probabilistic) "realities" one has never seen or directly experienced (and were never in one's external senses), nor ever will be without the aid of "extensional 
instrumentalities". All of the points in the last sentence are key to science and many other things and areas as well. Qualitative development does far more than simply "make one different" in the quantitative and incremental units sense that one finds in radical constructivism, British empiricism and American behaviorism. Qualitative development is "revolutionary" in the Kuhnian sense of the term and "pre and post" states and capabilities more than quite different.

One might like or want to presume that this "operational exemplar" of the oversized child is some sort of improvement over the Skinner mouse. However, inappropriate generalization is inappropriate generalization (just like Skinner) and one might venture a guess as to where radical subjectivism and Humian skepticism comes from given this operational exemplar and a variety of other problems associated with radical and educational constructivism as a philosophy or theory of learning or instruction. There is a long list of such fallacies and problems beginning with the numerous fallacies of British empiricism. British empiricists contended that the only way that one knows is through one's (external) senses and that we can never know if what we see, experience and "sense" is independent of the mind (i.e., real), two fallacies which are addressed in detail below. However, trying to cast and develop a theory of learning and a theory of instruction on the "lowest developmental stage" or "lowest possible denominator" or the "only-in-theexternal-senses fallacy is more than just a bad choice or a minor and trivial mistake. It is the epitome of reductionism which is reduction to absurdities while demanding everyone admire your new cloths.

This same "turn of the (last) century show" phenomenon is also observed in radical and educational constructivism in their views about sensation, sense memory, attention and perception and memory and cognitive processes and cognitive (as well as emotional which is rarely addressed) processing. One encounters "exact sense impressions,' and exact (passive) copies and copying Aunt Sally views and claims and claims about "transmissions" and the impossibility of transmitting knowledge or any two people having the exact same understanding or experience of anything. From these errors follows the lack of an objective reality of various kinds (remember Johnson's boulder and the Bishops foot please), which are the same arguments, rhetoric and claims one finds when one actually reads a lot of this turn of the (last) century literature and literature of the centuries before. The problems with all of these claims is what happens to them when they are compared to modern science and what we have learned in various areas including learning, since the turn of the (last) century, which is both enormous and incredible comparatively. When these comparisons are done (Grossberg, 1992; Kosslyn, 1996; Pinker, 1997; 2002), pretty much all of the claims and slogans vaporizes when compared to modern neurology, Zaldek's (Kaufman, 1975) fuzzy set theory and various aspects of artificial intelligence and expert system models and simulations and what is now know about cognition and probabilistic reasoning (Nickerson, 2004).

One also has the same turn of the (last) century quest for the holy grail of the "one and only generalized and fits all phenomena and instances" theory of learning in these various constructivist views. Psychology, learning theory and cognitive science gave that view and quest up over 50 years ago. It is as if everyone in education and science education, as well as educational constructivist (and their counterparts in other disciplines), have totally forgotten Gagne's classic and similar (educational) book on the topic called The Varieties of Human Learning, which was the darling of the science educational community in the seventies. Gagne identified and documented eight different kinds of human learning in the classical academic learning literature alone. He purposefully ignored and did not address the non-classical and emerging academic learning literature or the psychoanalytical, complex cognition or 'artificial' intelligence and expert systems learning literature. And all of these things and all of these areas have progressed a very, very long way since then (Carifio, 2005; Kolb and Whishaw, 1995). A modern physicist, biologist and chemist (or any practicing hard scientist for that matter) would be more than surprised to be told that there was one and only one theory (pretty much) that encompassed their entire discipline. How can or would a scientist or science educator implicitly or explicitly believe such a claim or view today about the area of human learning and development?

When one thinks of modern physics, chemistry or biology, one thinks of a very large collection of theories that encompass a very wide variety of phenomena that spill over into various "engineering" forms and applications. Why then (really) would one think that the discipline of learning would be so radically different, given the extraordinary complexity and capacities of human beings, as to basically have one and only one theory of learning and a very vague, anti-scientific and outdated one at that? Theoretical monism is "long gone" in the field of learning and in the field instruction even as a philosophy. Human beings learn in a wide variety of different ways often simultaneously which 
change with development and human beings are partially knowledgeable about all things at all time (the question is how partial) and intermittently rational (same question) and capable of both logical and metaphoric operativities of various kinds, which change with development. Human being, as (Nickerson, 2004) shows, are incredible and purposeful and often proactive non-linear probability engines, who operate and act both consciously and unconsciously (Freud, 1959), as well as observationally (Bandura, 1986) and automatically (Kintch, 1988), which is a view quite different from radical behaviorism or radical constructivism or educational constructivism. Many of these points are dealt with in detail elsewhere (Carifio, 2005) and full explication of these and associated points will also take an article all of its own, if not more. However, we want to make one other telling point here before we go on the last two points in this article, which are (1) Constructivism as creationist science and (2) The contradiction of radical and educational constructivist theory by the most basic of human capabilities: purposeful and unintentional deception and humor. In a word, how is it possible for you to deceive or be deceived by anyone or anything and what does that mean and how and why do you laugh and what does that mean. The simple and basic phenomena of deception and humor both contradict and falsify radical and educational constructivism and several other flavors of constructivism that there are in different areas of psychology, sociology and political science.

The last point that we wish to make in this section is that very little if any critical review and analysis of radical or educational constructivism has been formally done (of note in published form) by modern or current mainstream academic psychologists or learning theory specialists and experts, or essential commentary of any kind on this allegedly revolutionary and sweeping view and "psychological" theory. There has been no "Wow's" and "Right On's" from any of the leading lights or cutting edge theorists and researchers of the other core and fundamental disciplines we have mention here, despite Reigler (2005) rather wild and specious current claims to the contrary. In fact, one would have to say that there has indirectly been just the opposite occurrence (Pinker, 2002). The critical point of importance here is that there has been such a remarkable silence from all of these quarter on this topic and theoretical subject, that it should lead the reflective educator and academic to ask why and why if it really is "all that", as it has been made out to be. The reflective educator and academic in all disciplines should ask why are all of the supporting citations and positions for radical and educational constructivism primarily seminal theorists from the "turn of the (last) century show" and before. Is this fact the same or similar for the (basic) science content that one sees in research articles and classroom curricula today? What is "with that" really, other than what Whitehead had to say about the unfortunate relationship between old ideas and education; namely, "education is where old ideas go to die". One does indeed need to reflect and construct a view of these things, issues and problems, if one is a scientist and a serious science educator or a foundationally trained academic in the social sciences. However, it should also be clearly noted that many in the area of both psychology and sociology also engage in the "turn-of-the century show" in a variety of similar ways and espouse a form of constructivism that is not only from another time but also unsupported as well as often unchallenged and unexamined (Reigler, 2005), which will be comment on more below.

Creationist science: Radical and education constructivists (very similar to the Deweyians and Skinnerians before them) love to create metaphors, slogans and battle cries for their positions and views that reduce the necessity for close discussion, precise and theoretically explanatory representation, or questioning that may be used as catchy sound bites in what passes as serious discourse. Our intentions here is to create a metaphor, slogan and battle cry that aptly expresses the core and crux of the many problems with radical and educational constructivism that may aptly express these many problems and the unacceptability of these views and positions and particularly so in science education at a minimum. That metaphor and "catch phrase" is Radical and Educational Constructivism is Creationist Science. We have chosen this metaphor very carefully because of the many ironies inherent in it and the many ironies it conveys, as well as the many point-by-point comparisons that may be made between radical and educational constructivism and creationism and "creationist science", only a few of which can be noted here.

Recall please, the religious origins of radical constructivism in the work of Bishop Berkley and one will realize that there is a great deal of basic creditability, aptness and correctness in this metaphor, slogan, judgment and claim our ours. We also have other reasons for employing a device and strategy to make our points that both uses and relies upon inherent simultaneous ironical and oppositional contrasts that one may be perceived and understood or not. Such a "device" or strategy is (Freud, 1959) definition of wit, which is the core of humor, with humor being a particularly type of intentional slyness and purposeful 
deception and form of surprise at an alternative characterization, representation, meaning, or reality suddenly and surprisingly and somewhat automatically asserting itself in consciousness and falsifying (by comparative contrast) the characterization, representation, meaning, or reality that was currently there.

So it may actually be that post-positivist science is a joke after all as many logical positivist and creationists claim.

Constructivists are going to think that saying that constructivism is "creationist science" is a compliment and "a neat thing" and aptly characterizes their views and positions because (educational) constructivism is "all about" students actively creating meanings, representations and realities (as if any of these things could actually happen completely "passively"). Yes, meanings are indeed actively created in a great number of instances and particularly relative to "school learning tasks," but we have many points to make relative to this claim and view itself as well as its "contrast".

One would think from reading von Glaserfeld and the other leading educational constructivists that they had just invented or discovered reading, as well as language and text processing in the broadest sense of the terms in additional to memory schemas and inferential and deductive elaborative processes and cognitive processes occurring dynamically in real time! Further, one would also think that all of the work on these phenomena that has occurred in the last fifty years in the area of reading (Dagostino and Carifio, 1994) never mind psychology (Kintch, 1988) and the cognitive sciences (Baron, 1987; Spitzer, 1999) simply does not exist.

If one wants to quickly understand all of the many differences between radical and educational constructivism and constructivism in the main stream psychological and science literature, then will find it very helpful to read some of the basic and fundamental literature of reading processes as well as on language and "text" understanding and processing physiologically (Baron, 1987; Rose, 2003) as well as by machines (Spitzer, 1999) as opposed to "the turn of the (last) century' views of these phenomena. However, one of the "renaissances" currently occurring in science education (as well as other educational areas) is the view (if not rediscovery) that "reading' and "language' problems may be highly significant factors in all of the problems observed in the last few decades in the learning and understanding of science. As educational professionals and a practicing scientist and social scientist, all we have to say on this point is, "Ah, do you think?? Really??".
Characterizing radical and educational constructivism as creationist science is anything but a compliment. It is asserting that radical and educational constructivism is no different from creationism and the creationist movement and controversy in science and science education, as well as misguided and misdirected multi-cultural forces and movements and various relativisms that are also afoot in education and science education today; namely politically expedient orthodoxies and ideologies. And radical and educational constructivism is at one level not a philosophy of learning but a politics of learning and a political or sociological theory and that is very much part of its many problems, as it takes educational and science education to a place that science has never been comfortable historically all the way back to and before Galileo. Further, most practicing modern scientists do not espouse radical (or educational) constructivism even in weak forms in any of the basic science areas including mainstream psychology and learning theory. According to constructivists and science educators, it is practicing scientists who are out of step, behind the times and the problem and are in need to re-education, which brings us to the next creationist point.

Fensham (2004) points out Von Glasserfeld and other leading "theorists" and proponents of radical and educational constructivism, self-admittedly have very little background or training in philosophy, psychology, learning theory, or the nature of science and that their lack of common and basic knowledge about these disciplines and fields is far more than just "remarkable". No critic, or up-to-date specialists from these disciplines, disagrees with either Fensham or these constructivists on this self-admitted "lack of knowledge" point. Further, Fensham additionally points out that these same points are true for science educators and professors of science education currently and again there is no disagreement with him among critics of constructivism or up-to-date specialists from these various disciplines. However, Fensham also points out (and in more than just simple disbelief) that there is actually pride and in fact enormous pride in this lack of background, training and up-to-date knowledge in philosophy, psychology or learning theory among proponents and advocates of radical and educational constructivism and it is actually proffered and put forth as a virtue and desirable and admirable quality and what is needed to change and improve science education and then retroactively and automatically all of theses core parents disciplines and their history and knowledge-bases.

Radicals of all persuasions and flavors do have a penchant and fondness for taking all of their proponents 
out to the country side for "re-education" and a relearning of historical and empirical "facts". As (Matthews, 1993) has stated about radical and educational constructivists and their proponents and advocates: "Unfortunately matters of deep .... importance over which there have been centuries of debate too frequently appear almost as throw away lines in science education writing (p. 8)". Not letting alternative views, theories, data and fact get in the way of "true belief" is a hallmark of creationism, as well as selectively excluding all of these alternatives from the insulated and isolated community one attempts to create and control, which is science education today. Interdisciplinary science education, which is connected to the core disciplines now, is not exactly the battle cry and slogan of educational constructivists or science educators today. All of the above points should tell the reflective educator and science educators a number of important things not only about constructivism but the state of science education today. Outlining all of the point-by-point comparisons between radical and educational constructivism needs an article all of its own, but many of the most telling points have been stated in the different sections of this article. However, a few words now to be said about deception and humor to conclude this initial article.

Deception and humor: Radical constructivism and educational constructivism have incredibly outmoded views of human memory and consciousness and do not even acknowledge let alone seem to realize that "unconscious processes and processing" actually exist and occur. Human memories are basically inert, stable and "accurate in the sense of highly replicable once formed" in these views and constructivist views of memory are actually fairly blank-slate (behaviorists views) in character. Human memory is not seen as dynamic and constantly changing and something that is 'constructed and reconstructed' by semi-automatic processes, context cues and algorithms on every retrieval. Nor do they see memory as something that may modify itself unconsciously and automatically over time (Bartlett, 1932; Rose, 2003). As every theory of learning has at its core a theory of memory and the theory of memory that is at the core is key to the theory of learning inescapably, these are not trivial points, nor is ignoring memory and the theory of memory one has and is employing trivial as constructivist do in most instances. Not having a 'dynamic' view of memory has many implications and creates numerous problems relative to explaining phenomena and the ripple effects of an erroneous construct throughout one's 'theory". One cannot explain, for example, the concept of "false memories" (Loftus, 1996) which are very important and important phenomenon, nor can you really explain misconceptions and their surprising "growths" at all adequately, which is a hot topic in science education and for constructivists. This same point holds for consciousness.

When it comes to consciousness, one of the core tenants of radical constructivism is that one cannot know or prove that there is an objective reality and all consciousness is subjective. In fact a radical constructivist guru (Reigler, 2005) has gone so far as to claim that a particular neuroscientist has contended that neurons cannot distinguish between dreaming and wakeful consciousness (which is scientifically and neuro-chemically inaccurate (Rose, 2003), implicitly assuming that neurons are actually in charge of that particular detection rather than glial cells. The points here are two fold. First, there is a current movement that is attempting to "scientize" radical and educational constructivism because it has encountered very serious challenges from these quarters. These efforts have been fairly inaccurate and misguided. The second point has to do with the quality and character of many of the constructivists' claims and arguments. In terms of their contentions and claims about "objective reality", one needs only to counter: how can you know or prove that it (objective reality) is not there and real (selfrefutation), never mind that the weight of evidence and probability favor that it is as well as various logical arguments (see Popper for more formal and lengthy refutations). The point here is that everyone needs to give up a lot of sophomore philosophy and read certain classics in several fields and that human deception is the key observable fact one should focus on and explaining it theoretically, as deception and the ability to deceive and be deceived contradicts the various (erroneous) claims constructivists and their proponents make about objective reality, subjectivity and what may be know or not know and how. It should also be clearly noted that there are many neurologists and neuroscientists who hold almost all of the same erroneous views we have outline in this article up to this point and these neurologist and neuroscientists are not only behind the curve but their knowledge of cognitive psychology and learning theory predates the "70's show" and is also very rudimentary at best. Consequently, to quote neurologists or neuro-scientist to support or bolster one claims or views is not necessarily a sound, wise or prudent strategy and their views of these issues are not only often incorrect and out of date, but the very problem as Lashley (the top neurology and neuro-scientist of his time) so clearly and cogently outlined and analyzed in his famous and 
humorous lecture "In Search of the Engram" (Lashley, 1950). Deception and humor, therefore, are everywhere and ubiquitous and are very important (cognitive) phenomena.

It is fairly well know that explaining deception and humor are two of the key tests of any serious theory of learning or human functioning. Learning theorists (or at least current learning theorists) who are trying to evaluate a given learning theory, therefore, routinely apply these two tests to the theory to see how the theory does relative to these two criteria. A core problem with radical and educational constructivism that they simply cannot explain, let alone adequately explain, either deception (particularly intentional deception) or humor (and particularly intentional humor). If the radical and educational constructivist view and characterizations are correct, then no one should be able to intentional deceive another, which requires maintaining two alternative and contradictory constructions of reality in consciousness at once and one of them being a probabilistically true construction of the external world and others in it, which will either be confirmed or falsified!! Intentional deception and intentional Frankfurtian BS simply is not possible according to the radical and educational constructivist view, which is a view that is contradicted approximately a googolplex number of times each day world wide. And the same is true of humor (and particular satire and parody). No humor, satire or parody is possible according to the radical and educational constructivist view so there is none in this article, or at least so theoretically.

Explication these points about deception and humor each will take long articles of their own. However, it should be noted that from a radical constructivists view point deception would be explained as a case my constructing and actively creating a world where I was and would be purposefully wrong, fooled, continuously mislead, deceived, hoodwinked and BS'ed a very great deal of the time. If that sounds like the world of a three year old, masochist psychotic, or fool, then welcome to the real every day world, you are getting our points here, particularly if you recall our earlier point about the radical and educational constructivist's exemplar of the learner being an oversized child and an over-sized child who does not develop cognitively or qualitatively.

It is now a well documented fact that children learn to lie (to generate alternative representations) and that deception and lying (and holding two different and contradiction representations of 'reality' in mind at once) are critical parts and aspects of cognitive development (Bronson, 2008). Bright children learn to lie (to purposefully construct a false or inaccurate micro "reality" that others will accept as true) and to detect deception (to invalidate and prove false micro "realities" created by others or themselves) much earlier than other children (usually by ages 2 or 3 ). Lying and deception are related to intelligence (both early and later forms) and both are considered to be more complex and advanced cognitive skills than honesty (Bussey, 1992; Vrij, 2000). By age 4, almost all children will start experimenting with lying (constructing alternative presentations) and particularly so to avoid punishment or to manipulate situations to their advantage (Bok, 1999). So some small children are fairly good practicing scientists by the age of 2 relative to constructing experimental treatments to administer to others and falsifying the experimental treatments that others construct and other administer to them and this behaviors occur fairly automatically and without any (formal) constructivist (or constructivist science) education at all!.

It is now well established that we do instruct children in lying and deception (and that reality and people may deceive and be misperceived) through fairy tales and other such stories and the various white lies adults tell to each other as well as children that children know are not true (Bok, 1999). Children also learn from a variety of direct first hand (and usually unassisted) experiences that (objective) "reality" does not lie to them nor is it altered, deceived or fooled by lying to one's self or others about it or representing it in alternative ways; one falls no matter what and getting bitten or a rock dropped on one's foot hurts (recall Johnson and Bishop Berkley please) no matter what, even when you have shoes on. One may misperceive, misunderstand or not understand this (objective) reality, but it does not lie or misrepresent itself intentionally in any way as verbal representations and social realities do and children by the ages of 7 or 8 understand these facts and distinctions even if the understanding is intuitive (Lee et al., 2002).

By adolescence, $98 \%$ of the population engages in lying and deception of some form (ask any parent) but the lying is and becomes much, much more sophisticated, subtle and multi-purposed ranging from "white lies" and "social deflection" to maintain privacy and protecting feelings and self-esteem, to instruments and skills to gain power and control over others and situations and to manipulate people to achieve various desired ends (think romance here rather than business or politics). This type of lying and deception develops qualitatively throughout adulthood and its various forms are often labeled as "advanced cognitive skills" in leaders, diplomat, politicians, comics and professors, 
or as psychopathic and dangerous and destructive behaviors (i.e., Kohlberg's "saint or sociopath [perceptual] problem"). Various studies have shown that the bulk of adult lying is of the social deflectionprotection kind (Bronson, 2008) and that most adults are reasonably well-skilled at detecting these kinds of lies and mundane deceptions and contradictions and do so fairly routinely. More complex lies and deceptions require more knowledge and more cognitive development and logical skills and attention to details, anomalies and contradictions and thus training, practice and education. As many studies have shown, the majority of the adult populations world-wide does not fit this profile, which is part of the crux of the problem and why P.T. Barums of all kinds thrive and fool people, even in academia. From these problems come the problems with eye-witness testimony, observation, false memories and the two dozen other types of cognitive distortions that are documented in the psychological literature and as Einstein said, everything is not relative, everything is relative to something.

All constructions of "reality" are not equally correct or true and the second one admits that there is lying, deception and distortion one has self-negative one's constructivist argument and position. As (Eckert, 2006) has stated, to lie or deceive requires "A Theory of Mind". A theory of Mind is defined as a theory about how minds other than one's own work and process information and reality and constructing communications and behaviors according to this theory to obtained desired results. Everything is not subjective as radical and educational constructivist contend and we are not all prisoners of own subjective reality unable to communicate or interact with others, except perhaps if we are a new born child (but not likely given prenatal learning and development) or are completely psychotic or autistic. But these are the very images of the human learner that radical and educational constructivists essentially offer us, which one might politely assert are not exactly typical or accurate characterizations of the human beings or human learners!.

So, although we think of truthfulness and honesty as one of the chief virtues of children, a broad array of research (as well as simple logic) has shown that lying is the more advanced skill and cognitive state. A child or adult who is going to lie must recognize the truth, conceive of an alternate reality and be able to convince someone else of the veracity of the other reality proposed. Lying, therefore, demands both advanced cognitive development and social skills that honesty simply doesn't require and this simple fact is why lying and deception are considered to be major "developmental milestones". Lies and deceptions represent cognitive alternatives, disagreements, conflicts and dissonances that must be resolved. This ability to generate and test alternatives develops and occurs fairly automatically in small children to varying degrees unless there is purposeful conditioning or education not do such generating and testing. This generating and testing is in fact one of hallmark of the pre-operations stage of cognitive development. So all small children are "natural constructivists" and such constructions are fairly automatic processes, so the question of consequence is what happens to constrain children so and make them the passive and inert learners constructivist claim them to be? It could quite possibly be the beginnings of logical thinking (as inner reflection and processing is often construed as being passive), or it could be that learners are not as passive and inert as constructivist claim them to be, or it could be learned helplessness fostered by a particular mode and style of teaching or social interaction. Or perhaps it could be that that the problem is with radical and educational constructivism and its many incorrect contentions, which have been enumerated in some detail here as well as elsewhere. And then, of course, there is humor.

Humor, it should be noted, is a type of lying and humor has many of the features and characteristics of lying. Humor is also a developmental phenomenon and much of it, especially wit, often requires sophisticated cognitive development and cognitive skills and knowledge to get and understand the humor. As we have written and detailed elsewhere (Carifio and Perla, 2008), the joke (or humor) is essentially a model of the post-positivist view of the scientific method where two contradictory characterization of the same reality are introduced, one as dominant and the other latently (the rival hypothesis or theory) and then the key falsifying evidence is introduced (the punch line) and a rapid Gestalt switch occurs between the two alternative conceptions. The latent conception then becomes the dominant and correct characterization of the reality in the joke and one laughs as a release of energy in the reduction of the conflict between the two alterative views and from realizing that one was deceived and (good naturedly) fooled. The whole essence and art of the joke is to set the person up with view $\mathrm{A}$ and get them to believe it and then to falsify their belief in view A by introducing the punch line (the key falsifying evidence) that view $\mathrm{A}$ is incorrect and alternative view $B$ is indeed the case. If radical constructivism and educational constructivism were correct in what they assert and about human beings and learning, then no one would be able to tell a joke or be able to laugh at a joke told by others! As this "reality" is indeed not the case. This simple, basic and 
mundane fact and event (that occurs billions of times a day all over the world similar to lying and deception), is like Johnson's boulder on Bishop Berkley's foot and the simplest of refutations and falsification by elementary demonstration. Humor and deception vividly and conclusive demonstrates the fundamental incorrectness of the contentions and assertions of the radical and educational constructivists views, as well as their claims about learning and the learning process, even as a philosophy of learning let alone a psychological theory of learning and behavior. Radical and educational constructivism can be invalidated and falsified today as they were more than 200 years ago by elementary demonstration, simple observations, simple experiments and simple logical arguments and a long list of self-contradictions. It is not a psychological theory of learning, nor is it a philosophy of learning but rather it is a political theory of learning and one that needs to collapse quickly (namely, under go a rapid paradigm shift) as opposed to a languid and slow decline through endless attempted modifications.

\section{CONCLUSION}

One way to look at radical and educational constructivism and its many, many problems is to characterize it as a reactive over-emphasis and reactive over-focusing on the context of discovery as opposed to the context of justification, which seems to be heavy handedly dominating science education in the late seventies. There is some merit in pursuing this view as well as how the two view many be balanced and redressed into a different and new synthesis, but this rebalancing and synthesis will not occur until radical and educational constructivism is recognize for what it is and its essential incorrectness and numerous erroneous claims and contentions are recognized, understood and accepted.

Another way of looking at radical and educational constructivism is that it is a major example and exemplar of Frankfurtian BS and an attempt to speak way beyond one's grasp or knowledge but intentionally so and not accidentally or in a "striving to understand" fashion (Carifio and Perla, 2008). There is more than a great deal of merit in pursing this characterization or view of radical and educational constructivism particularly given the self-admitted and self-proclaimed lack of background and training in key and core areas by radical and educational constructivists and proclaiming this to a virtue. The question, however, would then become, "Where is all of the BS coming from and why"?
To answer this question in great part, we can look directly to Matthews but also to Fensham in particular.

There are many very serious professional education and professional development problems in science education just now that are a result of 30 years of isolation, insulation, inappropriate education and getting out of touch with the mainstream foundational disciplines and these problems simply have to be faced and faced now. Having to write an article like this (and the many others that have been written) in order to do professional development and professional education continuously and on the fly today both characterizes and represents the very core of the problem. That science education today can have an anti-scientific and creationist learning theory (and philosophy) at it core for most of its practitioners is not only astounding, as Fensham has said, but speaks volumes about the lack of adequate professional preparation and professional development that is occurring and how insular, disconnected and isolated science education has become, to the point where the lack of current and valid scientific knowledge about learning and human information processing from the neurons on up is a virtue and something to be proclaimed as a "good thing". Well maybe for poets but not for scientists and science educators. In a word, it is a time to begin some and bring about some major changes. There has been enough Frankfurtian BS in contemporary science education and it really is time to move on. It is the every day mundane and basic facts of reality and life that falsify and defeat radical and educational constructivism as well as Piaget's genetic epistemology upon which they are based.

What has been said above for science education is also true for social science and social studies education and those areas of psychology, sociology and political science that are proponents and advocates of these radical constructivist and educational constructivism view, models and contentions. One must see people and learners are something more than oversized children passively trapped in a subjective reality of the kind erroneous conceived of by Hume, Locke and Bishop Berkley. One cannot just passively accept the premise that is inherent in these views that learners cannot profit from the experience of other human being currently as well as those who came before them. One cannot just uncritically accept and advocate a view, model and program of action that cannot account for or explain something as ubiquitous, fundamental, mundane, critically important and typically human as deception and humor, the key twin tests of any alleged psychological theory of learning and human behavior. Radical and educational 
constructivism flunked these two key tests, which is not a triviality when it comes to making claims and assertions about human learning and behavior. We must all be as good a scientist as McKeachie was in 1974 and accept the results of a theory and view failing falsification tests and all of the other the available contradicting evidence and arguments and change our views and particularly so if we are proponents and advocates of radical and/or educational constructivism. It is time to reconnect to the mainstream in both learning theory and cognitive psychology and development and particularly so given the enormous educational and theoretical challenges we currently face. It is time for capitulation and collapse and a rapid paradigm shift to occur in these areas before we lose yet another generation of students, teachers and researchers.

\section{REFERENCES}

Ashcraft, M.H., 1997. Cognition. 2nd Edn., Prentice Hall, New York, ISBN: 13: 9780673467898, pp: 764 .

Bandura, A., 1986. Social Foundations of Thought and Action: A Social Cognitive Theory. 2nd Edn., Prentice-Hall, USA., ISBN: 013815614X, pp: 617.

Baron, R.J., 1987. The Cerebral Computer: An Introduction to the Computational Structure of the Human Brain. 1st Edn., Erlbaum Press, Hillsdale, New Jersey, USA., ISBN: 0805800379, pp: 552.

Bartlett, F.C., 1932. Remembering: A Study in Experimental and Social Psychology. 1st Edn., Cambridge University Press, London, ISBN: 0521483565, pp: 317.

Bok, S., 1999. Lying: Moral Choice in Public and Private Life. 2nd Edn., Vintage Press, New York, ISBN: 10: 0375705287, pp: 368.

Bronson, P., 2008. Learning to Lie. New York Magazine. http://nymag.com/nymag/po-bronson/

Bussey, K., 1992. Lying and truthfulness: Children's definitions, standards and evaluative reactions. Child Dev., 63: 129-137. http://cat.inist.fr/?aModele=afficheN\&cpsidt=5099 558

Carifio, J. and R. Perla, 2008. Inciting striving speech (i.e., BS) and imperfect dialogical exchanges is exactly what is needed in higher education today. $\mathrm{J}$. Soc. Sci., 4: 68-74. http://www.encyclopedia.com/doc/1G1-182288519.html

Carifio, J., 1979. Sequence, structure and NP-complete problems. J. Res. Sci. Teach., 16: 275-278. DOI: 10.1002/tea.3660160316
Carifio, J., 1993. Needed: A standard information processing model of learning and learning processes. Proceeding of the 16th Annual Meeting on Eastern Educational Research Association, Feb. 17-22, Clearwater, Fl., pp: 1-13. http://www.eric.ed.gov/ERICWebPortal/custom/po rtlets/recordDetails/detailmini.jsp?_nfpb=true\&_\& ERICExtSearch_SearchValue_0=ED356258\&ERI CExtSearch_SearchType_0=no\&accno=ED356258

Carifio, J., 2005. Toward a standard integrated information processing/cognitive model of learning. Proceeding of the Biennial Meeting of the International History, July 15-18, Philosophy and Science Teaching Group, Leeds, England, pp: 1-30. http://www.ihpst2005.leeds.ac.uk/papers/Carifio.pdf

Chomsky, N., 1959. A review of skinner's verbal behavior. $\quad$ Language, 35: 26-58. http://cogprints.org/1148/

Chomsky, N., 1975. The Logical Structure of Linguistical Theory. 3rd Edn., Plenum Press, New York, ISBN: 030630760X, pp: 573.

Cobb, P., 1994. Constructivism in mathematics and science education. Educ. Res., 23: 4. http://direct.bl.uk/bld/PlaceOrder.do?UIN=021037 $527 \&$ ETOC $=$ EN\&from $=$ searchengine

Collins, A.M. and E.F. Loftus, 1975. A spreading activation theory of semantic processing. Psychol. Rev., $\quad$ 82: 407-428. http://www.eric.ed.gov/ERICWebPortal/custom/po rtlets/recordDetails/detailmini.jsp?_nfpb=true\&_\& ERICExtSearch_SearchValue_0=EJ135579\&ERIC ExtSearch_SearchType_0=no\&accno=EJ135579

Craik, F. and R. Lockhart, 1972. Levels of processing: A framework for memory research. J. Verbal Learn. Verbal Behav., 11: 671-684. http://picard.montclair.edu/psychology/adams/craik -and-lockhart-1972.htm

Dagostino, L. and J. Carifio, 1994. Evaluative Reading and Literacy: A Cognitive View. 2nd Edn., Allyn and Bacon, Boston, ISBN: 0205140289, pp: 142.

Eckert, L., 2006. Theories of Mind: An Introduction. 2nd Edn., Rowan and Littlefield Press, America, ISBN: 074255063X, pp: 282.

Fensham, P., 2004. Defining and Identity: The Evolution of Science Education as a Field of Research. 1st Edn., Kluwer Academic Publisher, Dordecht, ISBN: 1402014678, pp: 260.

Frankfurt, H., 2005. On Bullshit. 1st Edn., Princeton University Press, New Jersey, ISBN: 10: 0691122946, pp: 67.

Freud, S., 1959. Collected Papers. 1st Edn., Basic Books, New York, ISBN: 039300743, pp: 280. 
Green, D., 1998. Cognitive Sciences: An Introduction. 2nd Edn., Blackwell, Oxford, ISBN: 10: 063119861X, pp: 432.

Grossberg, S., 1992. Neural Networks and Natural Intelligence. MIT Press, Cambridge, MA., ISBN: 0262570912, pp: 656.

Hooper, J. and D. Teresi, 1991. The Three Pound Universe. 6th Edn., Tarcher Inc., Los Angeles. ISBN: 0874776503, pp: 410.

Kaufman, A. 1975. Fuzzy Subset Theory. 1st Edn., Academic Press, Cambridge, MA., ISBN: 012423010, pp: 432.

Kintch, W., 1988. The role of knowledge in discourse comprehension: A construction-integration model. Psychol. Rev., 95: 163-182. http://www.eric.ed.gov/ERICWebPortal/custom/po rtlets/recordDetails/detailmini.jsp?_nfpb=true\&_\& ERICExtSearch_SearchValue_0=EJ386535\&ERIC ExtSearch_SearchType_0=no\&accno=EJ386535

Kolb, B. and I. Whishaw, 1995. Fundamentals of Human Neuropsychology. 4th Edn., Freeman and Co Ltd., New York, ISBN: 0716723875, pp: 712.

Kosslyn, S.M., 1996. Brain and Image, The resolution of the Imagery Debate. 1st Edn., MIT Press, Cambridge, MA., ISBN: 0262611244, pp: 528.

Kuhn, T.S., 1996. The Structure of Scientific Revolutions. 3rd Edn., University of Chicago Press, Chicago, ISBN: 0226458083, pp: 226.

Lakatos, I., 1970. Falsification and the Methodology of Scientific Research Programs. In: Criticism and the Growth of Knowledge, Lakatos, I. and A. Musgrave (Eds.). Cambridge University Press, Cambridge, ISBN: 0521096235, pp. 309-330.

Lashley, K., 1950. In search of the engram. Symp. Soc. Exp. Biol., 4: 454-482.

Lee, K., A. Cameron, J. Douchette and V. Taliva, 2002. Phantoms and fabrications: Young children's detection of implausible lies. Child Dev., 73: $1688-1702$.

http://www.ncbi.nlm.nih.gov/pubmed/12487487

Loftus, E.F., 1996. Memory distortion and false memory creation. Bull. Am. Acad. Psychiatry Law, 24: 281-295. http://cogprints.org/599/0/199802009.html

Matthews, M.R., 1993. Constructivism and science education: Some epistemological problems. J. Sci. Educ. $\quad$ Technol., 2: 359-370. http://adsabs.harvard.edu/abs/1993JSEdT...2..359M

Matthews, M.R., 1994. Discontent with constructivism. Stud. Sci. Educ., 24: 165-172. http://www.informaworld.com/smpp/ftinterface?co ntent $=\mathrm{a} 791758137 \& \mathrm{rt}=0 \&$ format $=$ pdf
Matthews, M.R., 1997. Introductory comments on philosophy and constructivism in science education. Sci. Educ., 6: 5-14. http://www.ingentaconnect.com/content/klu/sced/1 997/00000006/F0020001/00114411

Matthews, M.R., 2000. Constructivism in Science and Mathematics Education. In: National Society for the Study of Education 99-th Yearbook, Phillips, D.C. (Ed.). National Society for the Study of Education, Chicago, pp: 161-192.

Mayer, R.E., 2004. Should there be a three strike rule against pure discovery learning: the case for guided methods of instruction. Am. Psychol., 59: 14-19. http://www.ncbi.nlm.nih.gov/pubmed/14736316

McKeachie, W.J., 1974. The decline and fall of the laws of learning. Educ. Res., 3: 7-11. http://www.jstor.org/stable/1174605

McKeachie, W.J., 1976. Psychology in America's bicentennial year. Ame. Psychol., 31: 819-833.

Neisser, U., 1967. Cognitive Psychology. AppletonCroft, New York, ISBN: 10: 0131396676, pp: 351.

Nickerson, R., 2004. Cognition and Chance: The Psychology of Probabilistic Reasoning. 1st Edn., Psychology Press, Mahwah, New Jersey, ISBN: 10: 0805848991, pp: 472.

Nola, R., 1997. Constructivism in science and science education: A philosophical critique. Sci. Educ., 6: 55-83. DOI: 10.1023/A:1008670030605

Norman, D., 1976. Memory and Attention: An Introduction to Human Information Processing. 2nd Edn., Wiley, New York, ISBN: 0471651370, pp: 262.

Osborne, J., 1996. Beyond constructivism. Sci. Educ., 80: 53-82. http://direct.bl.uk/bld/PlaceOrder.do?UIN=002304 697\&ETOC $=$ RN\&from $=$ searchengine

Penrose, R., 1991. The Emperor's New Mind: Concerning Computers, Minds and the Laws of Physics. 2nd Edn., Penguin Books, New York, ISBN: 0140145346, pp: 480.

Pinker, S., 1997. How the Mind Works. Basic Books, 2nd Edn., The Penguin Press, Allen Lane, New York, ISBN: 0713992409, pp: 660.

Pinker, S., 1999. Words and Rules: The Ingredients of Language. 1st Edn., Basic Books, New York, ISBN:10: 0465072690, pp: 348.

Pinker, S., 2002. The Blank Slate: The Modern Denial of Human Nature. Viking Press, New York, ISBN: 0670031518, pp: 509.

Popper, K.R., 1969. Conjectures and Refutations: The Growth of Scientific Knowledge. 3rd Edn., Routledge and Kegan Paul, London, ISBN: 0710065078, pp: 431. 
Reigler, A., 2005. The constructivist challenge. Constr. Foundat., 1: 1-8.

Rose, S., 1999. From Brains to Consciousness? Essays on the New Sciences of the Mind. 2nd Edn., Penguin, UK., ISBN: 0691004692, pp: 278.

Rose, S., 2003. The Making of Memory. MIT Press, Cambridge, MA., ISBN: 0099449986, pp: 420.

Selfridge, O.G., 1959. Pandemonium: A Paradigm for Learning. In: The Mechanization of Thought Processes, Birnbaum, C. (Ed.). H.M. Stationary Office, London, ISBN: 0262010976, pp: 511-529.

Sokal, A. and J. Bricmont, 1998. Intellectual Imposters. 1st Edn., Profile Books, London, ISBN: 1861970749, pp: 276.

Spitzer, M., 1999. The Mind Within the Net. Models of Learning, Thinking, and Acting. 1st Edn., MIT Press, Cambridge, MA., ISBN: 10: 0262194066, pp: 359.
Suchting, W.A., 1992. Constructivism deconstructed. Sci. Educ., 1: 223-254. DOI: 10.1007/BF00430275

Suppes, D., 1979. The Structure of Scientific Theories. 2nd Edn., University of Illinois Press, New York, ISBN: 10: 0252006348, pp: 818.

Von Glaserfeld, E., 1995. Radical Constructivism. 1st Edn., Falmer Press, London, ISBN: 0750705728, pp: 210.

Von Glaserfeld, E., 2005. Thirty years of radical constructivism. Constr. Foundat., 1: 9-12.

Vrij, A., 2000. Detecting Lies and Deceit: The Psychology of Lying and the Implications for Professional Practice. 1st Edn., John Wiley, Chichester, England. ISBN: 047185316X, pp: 456. 